Doktoral Ilmu Hukum, Fakultas Hukum, Universitas Lampung, Bandar Lampung, Lampung, Indonesia.

Volume 2 Issue 2, July-December 2021: pp: 121-132 http://jurnal.fh.unila.ac.id/index.php/plr P-ISSN: 2723-262X E-ISSN: 2745-9306

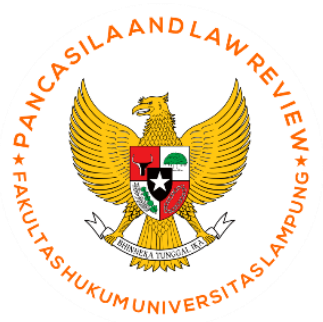

\title{
Standard Patterns of Considerations in Law, District Regulation and Qanun Based on Legal Rules in Indonesia
}

\author{
Husna Sartika \\ Universitas Syiah Kuala, Indonesia \\ husnasartika@gmail.com \\ Eddy Purnama \\ Universitas Syiah Kuala, Indonesia \\ eddypurnama@unsyiah.ac.id \\ Ilyas Ismail \\ Universitas Syiah Kuala, Indonesia \\ ilyas.ismail@unsyiah.ac.id
}

Submitted: Oct 6, 2021; Reviewed: Nov 20, 2021; Accepted: Nov 26, 2021

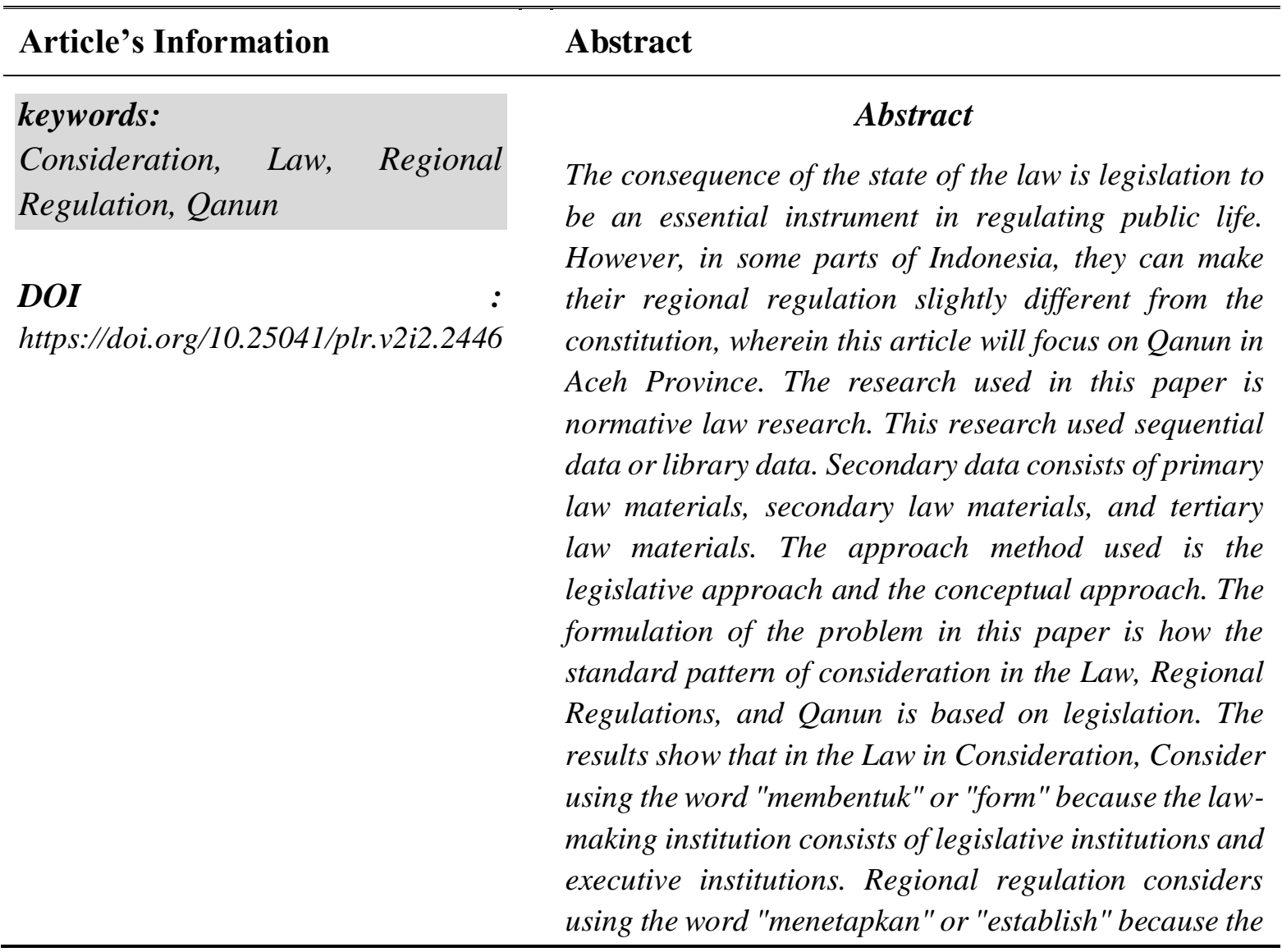


institution that makes local regulations is a local government consisting of elements of local governments and local people's representative councils. This consideration follows Annex II of Law Number 12 of 2011 on the Establishment of Legislation as amended by Law Number 15 of 2019. However, the Qanun used the word "membentuk" or "form" due following Article 233 paragraph (1) of Law Number 11 the Year 2006 on Aceh Governance and Annex II of Aceh Qanun Number 5 of 2011 on the Procedures for the Establishment of Qanun.

\section{A. Introduction}

After the reform era, Indonesia underwent fundamental changes in almost all aspects. The 1945 Constitution of the Republic of Indonesia as the fundamental law and the highest law in the Indonesian legal system has undergone significant changes. The number of provisions included in the original text of the 1945 Constitution includes 71 provisions. After undergoing four changes in a series of changes from 1999 to 2002, the provisions included in it became 199 provisions. Of the 199 provisions, only 25 came from the original text ratified by the Preparatory Committee for Indonesian Independence (PPKI) on August 18, 1945. The rest, namely 174 provisions, can be new provisions. ${ }^{1}$

One of the changes is Article 1 paragraph (3) of the 1945 Constitution of the Republic of Indonesia, which states that Indonesia is a state of law, thus placing laws and regulations in a strategic position that becomes the formal basis for policymaking and governance. According to the national legal system, legislation is a policy instrument to encourage Indonesia's national development. Legislation is a written regulation that contains legally binding norms in general and is established or determined by state institutions or authorised officials through the procedures stipulated in the legislation. ${ }^{2}$

The enactment of Law Number 12 of 2011 concerning the Establishment of Legislations cannot be separated from Indonesia's goal to be achieved. As a state of law, Indonesia aims to create standards and the rule of law in the Establishment of Legislations to produce harmonious and intact laws for national development that provide legal certainty and respects human rights principles. $^{3}$

In 2019, Law Number 12 of 2011 concerning the Establishment of Legislation which serves as a guide in forming laws and regulations in Indonesia, changed, namely Law Number 15 of 2019 concerning Amendments to Law Number 12 of 2011 concerning Formation of Legislation. However, there is no change for attachments I and II of the Act. The technique in preparing laws and regulations still refers to Attachment II of Law Number 12 of 2011 concerning the Establishment of Legislation.

The consideration for the amendment to the law is to strengthen the formation of sustainable laws and regulations. It is necessary to arrange and improve the mechanism for forming laws

\footnotetext{
${ }^{1}$ Jimly Asshidiqie, Pengantar Ilmu Hukum Tata Negara Jilid 1 (Jakarta: Sekretariat Jenderal dan Kepaniteraan MK RI, 2006), https://dkpp.go.id/wp-content/uploads/2018/11/pengantar_ilmu_hukum_tata_negara.pdf.pdf.

${ }^{2}$ Article 1 point 2 of Law Number 12 of 2011 concerning the Establishment of Legislations.

${ }^{3}$ Badan Pengembangan Sumber Daya Manusia Hukum dan HAM, Proses Penyusunan Peraturan Daerah (Depok: Kementerian Hukum dan Hak Asasi Manusia, 2018), http://bpsdm.kemenkumham.go.id/index.php/course/modul-best-practice-kumham.
} 
and regulations from planning to monitoring and reviewing. There are still shortcomings and have not accommodated the development of community needs so that it needs to be changed. ${ }^{4}$

Preparing legal products at the central and regional levels is guided by Law Number 12 of 2011 concerning the Establishment of Legislation. This is expected to meet the community's need for good laws and regulations in a definite, standard, and standard way and method that binds all institutions forming laws and regulations. ${ }^{5}$

The Regional Government's right to produce laws and regulations is a right granted directly by the Constitution in Article 18 paragraph (6) of the 1945 Constitution of the Republic of Indonesia. Based on Article 7 paragraph (1) of Law Number 12 of 2011 concerning the Establishment of Legislations, the laws and regulations' hierarchy are established by the House of Representatives with the joint approval of the President. Provincial Regulations ${ }^{6}$ Is a type of legislation under the Provincial Regulations Act is Legislations established by the Provincial Regional People's Representative Council with the Joint Agreement of the Governor. ${ }^{7}$

Constitution. Laws and Regional Regulations/Qanun are two types of statutory regulations referred to in Article 7 paragraph (1) of Law Number 12 of 2011 concerning the Establishment of Legislations. Systematically, the framework for drafting laws and regional regulations/qanuns is the same; however, the difference is in the consideration between the use of the word "form" in the law as stated in example number 23 Attachment II of Law Number 12 of 2011 concerning the Establishment of Legislation and the word "stipulate" in the Prevailing Laws below. This makes the writer interested in researching why the use of the word is different. ${ }^{8}$

To support this research as initial data, the author has read several regional regulations in 34 provinces in Indonesia on the Legal Information Documentation Network's website. This website is integrated with the jdihn.go.id portal, the National Legal Development Agency of the Ministry of Law and Human Rights of the Republic of Indonesia of each province. The author finds that several provinces use the word "form" or "determine" against several Regional Regulations promulgated between 2018 and 2019. Still, Aceh Province consistently uses the word "form". 9

This is certainly different from the provisions in Article 18 paragraph (6) of the 1945 Constitution of the Republic of Indonesia, which states that Regional Governments have the right to stipulate regional regulations and other regulations to carry out autonomy and assistance tasks. This is also different from considering the Laws and Regional Regulations mentioned in item 23 Attachment II of Law Number 12 of 2011 concerning the Establishment of Legislation. The author investigates further why there are differences in the consideration given to the use of the word "form" and the word "stipulate" in these laws and regulations.

Per the title, this article will discuss the "Standard Patterns of Considerations in Law, District Regulation and Qanun Based on Legal Rules." To get a common opinion on the paper's scope, it is first explained about the use of terms in the title. The standard pattern referred to here is' form' and 'stipulate'. These terms are used to form laws and regulations, so the problem

\footnotetext{
4 Law Number 15 of 2019 concerning Amendments to Law Number 12 of 2011 concerning the Establishment of Legislation.

${ }^{5}$ Badan Pengembangan Sumber Daya Manusia Hukum dan HAM, Proses Penyusunan Peraturan Daerah.

6 In the Elucidation of Article 7 paragraph (1) letter $\mathrm{f}$, it is stated that included in the Provincial Regulations are Qanuns that apply in Aceh Province and Special Regional Regulations (Perdasus) and Provincial Regulations (Perdasi) that apply in Papua Province and West Papua Province.

7 Article 1 point 7 of Law Number 12 of 2011 concerning the Establishment of Legislation.

${ }^{8}$ Cornelis Lay, "Political Linkages between CSOs and Parliament in Indonesia: A Case Study of Political Linkages in Drafting the Aceh Governance Law," Asian Journal of Political Science 25, no. 1 (2017): 130-50, https://doi.org/10.1080/02185377.2017.1297243.

${ }^{9}$ Moch Nur Ichwan, Arskal Salim, and Eka Srimulyani, "Islam and Dormant Citizenship: Soft Religious EthnoNationalism and Minorities in Aceh, Indonesia," Islam and Christian-Muslim Relations 31, no. 2 (2020): 21540, https://doi.org/10.1080/09596410.2020.1780407.
} 
that will be studied in this paper is how the standard pattern of weighing considerations in the Law, Regional Regulation, and Qanun is based on statutory regulations? An invitation formed by the Aceh People's Representative Council or Dewan Perwakilan Rakyat Aceh (DPRA) with the mutual consent of the Governor or the Legislation established by the Regency/City House of Representatives or Dewan Perwakilan Rakyat Kabupaten/Kota (DPRK) with the mutual consent of the Regent/Mayor. ${ }^{10}$ The Regional Regulations referred to in this paper are the laws established by the Provincial DPRD with the mutual consent of the Governor or the Legislative Regulations established by the Regency/City Regional People's Representative Council with the joint approval of the Regent/Mayor and Qanun, namely the Legislative Regulations.

Based on the background and identification of the problems mentioned above, the purpose of this paper is to obtain an explanation of the standard pattern of weighing considerations in Laws, Regional Regulations, and Qanuns based on Legal Rules.

Based on the problems to be studied, this research is normative legal research that uses library materials or secondary data as the primary source of research materials. ${ }^{11}$ According to Soerjono Soekanto, secondary data includes primary legal materials, secondary legal materials, and tertiary legal materials. ${ }^{12}$

The approach used in the research is a statutory approach and a conceptual approach. The approach to legislation is carried out by examining the laws and regulations related to the Standard Pattern of Consideration in Laws, Regional Regulations, and Qanuns Based on Legislations. The conceptual approach is carried out by reviewing the literature as well as the opinions of experts on the conception of consideration by considering laws, regional regulations, and qanuns based on legal rules to support the justification of the conception of taking into account the regulated considerations.

The data that has been obtained will be arranged in a comprehensive arrangement. Then it will be analysed juridically-qualitatively based on the existing legal norms. The analysis will be carried out on primary, secondary, and tertiary legal materials so that the results of this analysis become a comprehensive prescriptive analysis.

\section{B. Discussion}

In writing this research, several theories and principles will be discussed. Satjipto Raharjo argues that theory explains by organising and systematising the discussed problems. Meanwhile, according to M. Solly Lubis, the theory is a rational explanation under the object described and supported by empirical facts to be declared authentic. To research "Standard Patterns of Considerations in Law, District Regulation and Qanun Based on Legal Rules," the theoretical approach and the concept approach are used as follows:

\section{a. Authority Theory}

Ferrazi defines authority as the right to carry out one or more management functions, including regulation and standardisation, administration, and supervision of a particular matter. ${ }^{13}$ Then according to Prajudi Atmosudirjo, authority is formal power, the power that comes from legislative power (given by law) or from executive/administrative power. Authority is power over a particular group of people or power over a specific area of

\footnotetext{
${ }^{10}$ R. Michael Feener, “Engineering Transformations in the 'Religion-Development Nexus': Islamic Law, Reform, and Reconstruction in Aceh," Religion 51, no. 1 (2021): 40-57, https://doi.org/10.1080/0048721X.2020.1792051.

${ }^{11}$ Soerjono Soekanto and Sri Mamudji, Penelitian Hukum Normatif : Suatu Tinjauan Singkat, 17th ed. (Jakarta:

Rajawali Press, 2015).

12 Soekanto and Mamudji.

${ }^{13}$ Ganjong, Pemerintahan Daerah Kajian Politik Hukum, 1st ed. (Bogor: Ghalia Indonesia, 2007).
} 
government that is unanimous. Within authority, there are powers. Authority is the power to carry out a public legal act. ${ }^{14}$

The concept of the theory of authority, according to Philipus M Hadjon, is that every government action is required to be based on legitimate authority. This authority is obtained through three sources: attribution, delegation, and mandate. Attribution authority is usually outlined through the division of state power by law. Delegation authority comes from the attributive delegation of authority, while the mandate does not occur as a delegation of authority. ${ }^{15}$

Furthermore, Philipus M. Hadjon made a distinction between delegation and mandate. If the delegation process originates from one government organ to another, statutory regulations and the responsibility and accountability shift to the delegates. The delegate can no longer use that authority, except after a revocation by adhering to the "contrarius actus" principle. This means that every change and revocation of a regulation implementing legislation is carried out by the official who stipulates the regulation in question and carries out an equivalent or higher regulation. In terms of mandates, delegation procedures are in the context of routine superior-subordinate relationships. The responsibility and accountability remain with the mandate giver. At any time, the mandate giver can use the delegated authority himself. ${ }^{16}$

According to the constitutional law review, this attribution is shown in authority possessed by government organs in carrying out their government based on the authority established by the legislators. This attribution refers to the original authority based on the constitution or statutory regulations. ${ }^{17}$

\section{b. Legal Norm Hierarchy Theory}

The theory regarding the level of legal norms (Stufentheorie) argues that legal norms are tiered and layered in a hierarchy (organisation). A lower norm applies, originates, and is based on, a higher norm. And so until a norm that cannot be traced further is hypothetical and fictitious, namely the basic norm (Grundnorm). Valid, sourced, and based on higher norms. ${ }^{18}$ Hans Kelsen put forward the theory of grading legal norms.

Understanding the hierarchy of norms illustrates that the legal system is arranged in stages from the highest rank or level, namely the basic norm to the lowest level norm. Legal norms of a lower degree must be based on and must not conflict with norms of a higher degree. The contradictory nature of higher degree results in the cancellation of the validity of the legal norm. Therefore, the higher degree norm is the basis or source of law for the lower level norm. Hans Kelsen's concept of a hierarchy of legal norms aligns with the legal principle "Lex superiori derogate legi inferiori", which means that legal norms with a higher degree override legal norms with lower degrees. ${ }^{19}$

The theory of legal norm hierarchy proposed by Hans Kelsen was later developed by his student Hans Nawiasky concerning a country. Hans Nawiasky in his book "Allgemeine Rechtslehre" argues Hans Kelsen's theory. According to Nawiasky, a legal norm is always layered and tiered; namely, the lower norm applies, is based on, and originates from a higher norm until it reaches the highest norm, which is called the basic norm. Hans

\footnotetext{
${ }^{14}$ Helmy Boemiya, "Teori Kewenangan Dan Sumber-Sumber Kewenangan (Atribusi, Delegasi, Dan Mandat)," wordpress, 2014, https://boeyberusahasabar.wordpress.com/2013/12/10/sumber-kewenangan-atribusi-delegasidan-mandat/.

15 Philipus M. Hadjon, Pengantar Hukum Administrasi Indonesia (Yogyakarta: Universitas Gadjah Mada, 1997).

${ }^{16}$ Boemiya, "Teori Kewenangan Dan Sumber-Sumber Kewenangan (Atribusi, Delegasi, Dan Mandat)."

${ }^{17}$ Lutfi Effendi, Pokok-Pokok Hukum Administrasi, 1st ed. (Malang: Bayu Media, 2003).

${ }^{18}$ Hans Kelsen, General Theory of Law and State, 1st ed. (New York: Routledge, 2005).

${ }^{19}$ Badan Pengembangan Sumber Daya Manusia Hukum dan HAM, Ilmu Perundang-Undangan (Depok: Kementerian Hukum dan Hak Asasi Manusia, 2018).
} 
Nawiasky added that legal norms are also grouped in addition to layered and tiered norms. Nawiasky was grouped into 4 major groups, namely:

1. Staatsfundamentalnorm (fundamental norms of the state);

2. Staatsgrundgezets (fundamental rules of the state);

3. Formell Gezetz (formal law);

4. Verordnung dan Autonome Satzung (implementing rules and autonomy regulations)

The norms mentioned above always exist in a legal norm arrangement in each country, although the terms and the number of norms are different. In Indonesia, the fundamental norm of the state is Pancasila, and this norm must be used as a guiding star for designers in forming laws and regulations. ${ }^{20}$

The Indonesian legal system related to the types and hierarchies of statutory regulations in Indonesia is based on the 1945 Constitution of the Republic of Indonesia. The legal order that forms the frame of legal norms is structured in a legal system, where these norms must not override or conflict with other legal norms. Thus, as a state of law, its legal system must be structured in a hierarchical order of legal norms and should not conflict with each other both vertically and horizontally. ${ }^{21}$

The hierarchy of laws and regulations in Indonesia as regulated in Article 7 paragraph (1) of Law Number 12 of 2011 concerning the Establishment of Legislation, namely:

a. the 1945 Constitution of the Republic of Indonesia;

b. Decree of the People's Consultative Assembly;

c. Laws/Government Regulations in Lieu of Laws;

d. Government regulations;

e. Presidential decree;

f. Provincial Regulations; and

g. Regency/City Regional Regulations.

Then in Article 7 paragraph (2) of Law Number 12 of 2011 concerning the Establishment of Legislations, it is stated that the legal force of legislation is following the hierarchy. Thus, the 1945 Constitution of the Republic of Indonesia is the highest regulation in the Indonesian legal system and becomes the basis for forming legislation under it. The regulations that are formed must not conflict with the regulations above. For example, Laws or Government Regulations and Governor Regulations must not conflict with Regional Regulations.

According to the online version of the Indonesian Dictionary (Kamus Besar Bahasa Indonesia Daring), the word "consider" or "konsideran/kon.si.de.rans/n" has the meaning of considerations that are the basis for making decisions, regulations, and others. ${ }^{22}$ Meanwhile, in the Indonesian-Indonesian Law Dictionary Online Law Dictionary, the word consideration is defined or interpreted as a brief description of the main ideas considered and the reasons for the formation of legislation. Specifically, on Regional Laws and Regulations, the preamble contains philosophical, sociological, and juridical elements. These elements are considered and the reasons for their formation whose writings are placed sequentially from philosophical, sociological, and juridical.

From the two definitions or meanings of the above considerations, we can understand that the consideration is a consideration in a statutory regulation that reflects or describes the urgency of the legislation's establishment. In Article 1 number 2 of Law Number 12 of 2011 concerning the Establishment of Legislations, it is stated that the meaning of legislation is a written regulation that contains legally binding norms in general and is established or

\footnotetext{
${ }^{20}$ Suhariyono AR, (Hand-Book/Modul) Pembentukan (Perancangan) Peraturan Perundang-Undangan (Jakarta: Kementerian Hukum dan HAM RI, 2008).

${ }^{21}$ I Nengah Suantra, "Naskah Tutorial Teori Legislasi Dalam Pembentukan Peraturan Daerah" (Denpasar, 2016), https://simdos.unud.ac.id/uploads/file_pendidikan_1_dir/82772d18fda11e83fed7290646195f01.pdf.

${ }^{22} \mathrm{KBBI}$, “Arti Konsiderans,” in Kbbi (KBBI, 2021), https://kbbi.web.id/konsiderans.
} 
determined by a state institution or authorised official through a procedure established stipulated in the legislation.

Article 20 paragraph (1) of the 1945 Constitution of the Republic of Indonesia states that the power to form laws rests with the House of Representatives or Dewan Perwakilan Rakyat (DPR). Then in Article 20 paragraph (2) of the 1945 Constitution of the Republic of Indonesia stipulates that every bill or Rancangan Undang-Undang (RUU) discussed by the DPR and the President for mutual approval. Therefore, the right to form laws rests with the DPR as a legislative body and the President as an executive body.

As a legal community unit with autonomy, the region can regulate and manage its region according to its aspirations. Moreover, the interests of its people aligned with the national legal order and the public interest. One of the rights, namely the right to produce laws and regulations by the Regional Government, is a right granted directly by the Constitution in Article 18 paragraph (6) of the 1945 Constitution of the Republic of Indonesia.

Based on Article 7 paragraph (1) of Law Number 12 of 2011 concerning the Establishment of Legislative Regulations, it is stated that Provincial Regional Regulations. ${ }^{23}$ Provincial Regulations are Legislations established by the Provincial Regional People's Representative Council with the Joint Agreement of the Governor. ${ }^{24}$

The amendments to the 2000 MPR general session which amended Article 18, Article 18A, and Article 18B of the 1945 Constitution of the Republic of Indonesia, according to Jimly Asshiddiqie, has changed the format of our country from a "rigid" unitary state to a "dynamic" unitary state. This is due to two considerations:

a. Federalist arrangements are possible in the national and the regional government's relationships.

b. It is possible to develop a pluralistic autonomy policy because each region can apply different patterns of autonomy. This diversity of relationship patterns is evidenced by accepting the principle of special autonomy for Aceh and Papua. ${ }^{25}$

The model of regional autonomy and decentralisation's in Indonesia after the 1945 constitutional amendment has been recognised by Lecturer and Professor of the Faculty of Law of the National University of Singapore (NUS), Gary F. Bell, who wrote:

The Indonesian model is unique because it does not fit perfectly into any specific model. For political and historical reasons, a federation was not an option for Indonesia, which the constitution describes as a unity state. Nonetheless, as amended in 2000 (second amendment), the constitution creates regional authorities (provinces, regencies, and cities) democratically elected. It enshrines the principle of regional autonomy and authorises the local government to adopt regulations. More importantly though article 18(5), the constitution grants the regional government the broadest autonomy, effectively giving the local government's residual powers-unless a statute explicitly grants power to the central government, the power belongs to local government. All power of the state in principle belong to the regional government". ${ }^{26}$

Article 4 paragraph (1) of the 1945 Constitution of the Republic of Indonesia states that the President of the Republic of Indonesia holds governmental power according to the constitution. The philosophical meaning in these provisions is that the holder of Government

\footnotetext{
23 In the Elucidation of Article 7 paragraph (1) letter f, it is stated that included in the Provincial Regulations are Qanuns that apply in the Aceh Province and Special Regional Regulations (Perdasus) and Provincial Regulations (Perdasi) that apply in Papua Province and West Papua Province.

24 Article 1 point 7 of Law Number 12 of 2011 concerning the Establishment of Legislation.

25 Jimly Asshiddiqie, Konstitusi Dan Konstitusionalisme. (Jakarta: Konstitusi Press, 2005).

${ }^{26}$ Gary F. Bell, "Decentralisation in Indonesia-Theory and Practice," Jurnal Hukum Bisnis 23, no. 1 (2004): 7.
} 
power in the Unitary State of the Republic of Indonesia is the President, including the functions of evaluation, clarification, supervision of regulations issued by the Regional Government. Thus, it can be analogised that the regulations issued by the Regional Government/Head of Regions must be in line with the regulations laid down by the Government/President. It can be understood together that the Central Government and Regional Governments are a unified whole. ${ }^{27}$ Everything in them is a unified commitment that must be understood, implemented with complete discretion for the organisers. The aim is to realise a better national and state life order to achieve the ideals set out in the preamble to the 1945 Constitution of the Republic of Indonesia. ${ }^{28}$

The relationship of authority between the central government and provincial, district, and city-regional governments, or between provinces and regencies and cities, is regulated by law with due observance of the specificity and diversity of the regions. ${ }^{29}$ The state recognises and respects memorable or special regional government units regulated by law. ${ }^{30}$

According to the national legal system, legislation is a policy instrument to encourage Indonesia's national development. Indonesia places laws and regulations in a strategic position as a formal basis for national policymaking and governance as a state of law. The enactment of Law Number 12 of 2011 concerning the Establishment of Legislative Regulations cannot be separated from the goals to be achieved by Indonesia as a state of law to create legal standards and. National order development that provides legal certainty and respects human rights principles. $^{31}$

The technique of making laws and regulations began to develop in the 19th century: the time of the emergence of significant codifications. Driven by the need to write many laws, people began to think about the best system. One of the points of concern is the problem of word choice and sentence structure. Each legislation's language is closely related to the regulated material (from one level to above or below). The higher the language used, the more abstract, and vice versa. The lower the level the language used is easy to implement, and vice versa. ${ }^{32}$

In the formation of laws and regulations, it is necessary to understand the systematics of draft laws, namely:

A. Legislation Title;

B. The opening consists of:

1. Phrase of the "Grace of God Almighty";

2. Positions of Officials;

3. Preamble;

4. Legal basis;

5. Dictum.

C. The main section consists of:

1. Provisions;

2. Main regulated provisions;

3. Criminal provisions (if necessary) ${ }^{33}$;

\footnotetext{
${ }^{27}$ Michael Buehler and Dani Muhtada, "Democratisation and the Diffusion of Shari'a Law," South East Asia Research 24, no. 2 (2016): 261-82, https://doi.org/10.1177/0967828X16649311.

28 Constitutional Court Decision Number 56/PUU-XIV/2016, pg. 54-55.

29 Article 18A paragraph (1) of the 1945 Constitution of the Republic of Indonesia.

30 Article 18B paragraph (1) of the 1945 Constitution of the Republic of Indonesia.

${ }^{31}$ Badan Pengembangan Sumber Daya Manusia Hukum dan HAM, Proses Penyusunan Peraturan Daerah.

${ }^{32}$ Badan Pengembangan Sumber Daya Manusia Hukum dan HAM, Bahasa Peraturan Perundang-Undangan (Depok: Kementerian Hukum dan Hak Asasi Manusia, 2018).

${ }^{33}$ Simon Butt, "Religious Conservatism, Islamic Criminal Law and the Judiciary in Indonesia: A Tale of Three Courts," The Journal of Legal Pluralism and Unofficial Law 50, no. 3 (2018): 402-34, https://doi.org/10.1080/07329113.2018.1532025.
} 
4. Transition terms (if necessary);

5. Closing provisions.

D. Closing

E. Elucidation (if necessary)

F. Appendix (if necessary). ${ }^{34}$

Based on laws and regulations, the consideration in a framework is in the opening position after the phrase "By the Grace of God Almighty" and the position Forming the Legislation. ${ }^{35}$ The preamble contains a brief description of the main ideas that form the background and reasons for making laws and regulations. ${ }^{36}$

If a statutory regulation is formed based on the attribution authority, then in the consideration, it contains philosophical, sociological, and juridical foundations which are written sequentially. However, suppose a statutory regulation is formed based on the authority of the delegation. In that case, the formulation of thoughtful consideration is sufficient to contain the provisions of an article or several articles of the statutory regulation ordering the establishment of further statutory regulation.

The philosophical basis is a consideration or reason that illustrates that the regulations that are formed take into account the views of life, awareness, and legal ideals, which include the spiritual atmosphere and the philosophy of the Indonesian nation originating from Pancasila and the preamble to the 1945 Constitution of the Republic of Indonesia. The sociological basis is the consideration or reason that describes that the regulations are formed to meet the community's needs in various aspects. The sociological basis concerns empirical facts regarding the development of problems and needs of the state community. ${ }^{37}$

The juridical basis is a consideration or reason that illustrates that regulations are formed to overcome legal problems or fill legal voids by considering existing rules, which will be changed or revoked to ensure legal certainty and a sense of justice for the community. The juridical basis concerns legal issues related to the substance or material that is regulated so that it is necessary to form new laws and regulations. Some of these legal issues include outdated regulations, inharmonious or overlapping regulations, types of regulations that are lower than the law so that their practice is weak, the regulations already exist but are inadequate, or the regulations do not exist at all. ${ }^{38}$

In the book "Perihal Undang-Undang" or "About the Law," written by Jimly Asshiddiqie writes that the state as an organisation of general power can make three kinds of legally binding decisions, namely decisions that are general and abstract are usually regulating (regeling). At the same time, individual and concrete decisions contain administrative determinations (beschikking) or decisions in the form of the judge's verdict, which is usually referred to as the term decision. ${ }^{39}$

Then Maria Farida Indrati S. in her book "Ilmu Perundang-undangan: Jenis, Fungsi, Materi" or " the Science of Legislation: Types, Functions, Content Materials" explains the legal norms can be divided into legal norms that apply continuously (dauerhaftig) and legal norms that apply once-finished (einmahlig). It means a legal norm that applies continuously (dauehaftig) is a legal norm that is not limited by time. It can apply continuously until the regulation is revoked or replaced with a new regulation. Meanwhile, a legal norm that applies once and is completed (einmahlig) is a legal norm that applies only once, so after the stipulation,

\footnotetext{
34 Appendix II of Law Number 12 of 2012 Concerning the Formation of Legislation, pg. 11

35 Law Number 12 of 2012

${ }^{36}$ AR, (Hand-Book/Modul) Pembentukan (Perancangan) Peraturan Perundang-Undangan.

37 Appendix II of Law Number 12 of 2012 Concerning the Formation of Legislation, pg. 11

38 Law Number 12 of 2012

${ }^{39}$ Adi Condro Bawono, "Perbedaan Keputusan Dengan Peraturan,” Hukum Online, 2012,

https://www.hukumonline.com/klinik/detail/ulasan/lt4f0281130c750/perbedaan-keputusan-dengan-peraturan/.
} 
the legal norm is completed. ${ }^{40}$ Legal norms included in statutory regulations that regulate (regeling) are legal norms that are generally abstract and apply continuously. Legal norms that are stipulating (beschikking) are legal norms that are individual-concrete and once completed. ${ }^{41}$

From the above understanding, Laws and Regional Regulations/Qanun are included in the types (regeling), regulating, general, and abstract.

The implementation of Law Number 12 of 2011 concerning the Establishment of Legislation and its attachments is one of the efforts to provide national guidelines in preparing laws and regulations. The Laws and Regional Regulations/Qanun are included in the regulatory, general, and abstract type of regulation. The formed laws and regulations have definite, standard, and standard methods and methods that bind all institutions forming laws and regulations.

Article 18 paragraph (6) of the 1945 Constitution of the Republic of Indonesia states that "Regional governments have the right to stipulate regional regulations and other regulations to carry out autonomy and assistance tasks". Then in Appendix II point 23 of Law Number 12 of 2011 concerning the Establishment of Legislation, examples are given of the use of the word form for laws and the word stipulate for regional regulations. This is a juridical consequence of the concept of Regional Government adopted in Law Number 23 of 2014 concerning Regional Government.

Suppose the government's administration at the centre consists of executive, legislative, and judicial institutions. In that case, the concept of implementing Regional Government is carried out by the Regional People's Representative Council or Dewan Perwakilan Rakyat Daerah (DPRD) and regional heads. DPRD and regional heads are located as elements of regional government administrators who the people mandate to carry out government affairs handed over to the regions. Thus, the DPRD and regional heads are positioned as equal partners with different functions. The DPRD has the function of forming Regional Regulations, budgeting, and supervision, while the regional head carries out the function of implementing the formation of Regional Regulations and Regional policies. Therefore, there is a difference in forming institutions between laws and regional regulations if the formation of the law involves two institutions, namely the executive and legislative institutions. While in the region, there is only 1 , namely the regional government. ${ }^{42}$

The concept of governance at the centre and the regions is reflected in consideration of statutory regulation. Where if the law is formed by two institutions, namely the executive and legislative institutions so that in the considerations, the word "forms" is used and for statutory regulations other than the law uses the word "stipulates" because the institution that forms it is only one.

Although Law Number 12 of 2011 does not regulate in detail the use of the words determine and form, we can see in point 23 of Appendix II of Law Number 12 of 2011. This is also explained in the Question and Answer Book Regarding the Establishment of Legislation at the Central Level issued by the Directorate General of Legislation, Ministry of Law and Human Rights, RI in collaboration with Japan International Cooperation Agency (JICA) in 2019. This book states that basically Law Number 12 of 2011 does not guide on when to use the words "formed" and "stipulated". The use of the two terms refers to the institution that forms or establishes the regulation. The term "established" is used for laws, and "established" is used for statutory regulations under the law. ${ }^{43}$

\footnotetext{
${ }^{40}$ Maria Farida Indrati Soeprapto, Ilmu Perundang-Undangan : (Jenis, Fungsi, Dan Materi Muatan) (Jakarta: Kanisius, 2007).

${ }^{41}$ Soeprapto.

${ }^{42}$ Elucidation of Law Number 23 of 2014 concerning Regional Government.

${ }^{43}$ Kementerian Hukum dan HAM and Japan International Cooperation Agency, Buku Tanya Jawab Seputar Pembentukan Peraturan Perundang-Undangan Di Tingkat Pusat (Jakarta: Kementerian Hukum dan Hak Asasi Manusia, 2019).
} 
However, the Qanun, a regional regulation in Aceh Province, has special rules relating to the formation of the Qanun and the rules that apply nationally. This can be seen in Article 233 paragraph (1) of Law 11 of 2006 concerning the Government of Aceh, which states that "Qanun was formed in the context of administering Aceh Government, district/city administrations, and implementing co-administration tasks". Then in Appendix II of Aceh Qanun, Number 5 of 2011 concerning Procedures for Formation of Qanun provides an example that Aceh Qanun and Regency/City Qanun consider using the word "form" instead of "stipulate" as are local regulations in other provinces in Indonesia. This is recognised in Article 171 of the Regulation of the Minister of Home Affairs Number 80 of 2015 concerning Regional Legal Products as amended by Regulation of the Minister of Home Affairs Number 120 of 2018 concerning Amendments to the Regulation of the Minister of Home Affairs Number 80 of 2015 concerning Regional Legal Products. The regulation also applies to the Province of the Special Region of Yogyakarta, the Province of the Special Capital Region of Jakarta, the Province of Aceh, the Province of Papua, and the Province of West Papua. Still, the regulation provides room for the difference if special rules regulate following statutory regulations. The Aceh Province has a particular format for Qanun, namely as regulated in Aceh Qanun Number 5 of 2011 concerning Procedures for Formation of Qanun.

\section{Conclusion}

The standard pattern of weighing considerations on Regional Regulations and Qanuns is based on statutory regulations from the description above. The consideration uses the word "form" because the law-forming institutions consist of legislative institutions and executive institutions. The Regional Regulations use the word "stipulate" because the institution is a regional government consisting of elements of the regional government and the regional people's representative council. This follows Appendix II of Law Number 12 of 2011 concerning the Establishment of Legislations as amended by Law Number 15 of 2019 concerning Amendments to Law Number 12 of 2011 concerning the Establishment of Legislation. For Qanun, although the same in the hierarchy of Legislation with Regional Regulations, using the word form because there are special rules that regulate it, namely under Article 233 paragraph (1) of Law Number 11 of 2006 concerning the Government of Aceh and Attachment II of Aceh Qanun Number 5 of 2011 concerning Procedures for Formation of Qanun.

\section{Bibliography}

\section{A. Journal}

Bell, Gary F. "Decentralisation in Indonesia-Theory and Practice." Jurnal Hukum Bisnis 23, no. 1 (2004): 7.

Buehler, Michael, and Dani Muhtada. "Democratisation and the Diffusion of Shari'a Law." South-East Asia Research 24, no. 2 (2016): 261-82. https://doi.org/10.1177/0967828X16649311.

Butt, Simon. "Religious Conservatism, Islamic Criminal Law and the Judiciary in Indonesia: A Tale of Three Courts." The Journal of Legal Pluralism and Unofficial Law 50, no. 3 (2018): 402-34. https://doi.org/10.1080/07329113.2018.1532025.

Feener, R. Michael. "Engineering Transformations in the 'Religion-Development Nexus': Islamic Law, Reform, and Reconstruction in Aceh." Religion 51, no. 1 (2021): 40-57. https://doi.org/10.1080/0048721X.2020.1792051.

Ichwan, Moch Nur, Arskal Salim, and Eka Srimulyani. "Islam and Dormant Citizenship: Soft Religious Ethno-Nationalism and Minorities in Aceh, Indonesia." Islam and Christian-
Muslim
Relations
31 ,
no.
2
(2020):
215-40. 
https://doi.org/10.1080/09596410.2020.1780407.

Lay, Cornelis. "Political Linkages between CSOs and Parliament in Indonesia: A Case Study of Political Linkages in Drafting the Aceh Governance Law." Asian Journal of Political Science 25, no. 1 (2017): 130-50. https://doi.org/10.1080/02185377.2017.1297243.

\section{B. Books}

AR, Suhariyono. (Hand-Book/Modul) Pembentukan (Perancangan) Peraturan PerundangUndangan. Jakarta: Kementerian Hukum dan HAM RI, 2008.

Asshiddiqie, Jimly. Konstitusi Dan Konstitusionalisme. Jakarta: Konstitusi Press, 2005.

Asshidiqie, Jimly. Pengantar Ilmu Hukum Tata Negara Jilid 1. Jakarta: Sekretariat Jenderal dan Kepaniteraan MK RI, $2006 . \quad$ https://dkpp.go.id/wpcontent/uploads/2018/11/pengantar_ilmu_hukum_tata_negara.pdf.pdf.

Badan Pengembangan Sumber Daya Manusia Hukum dan HAM. Bahasa Peraturan Perundang-Undangan. Depok: Kementerian Hukum dan Hak Asasi Manusia, 2018.

- Ilmu Perundang-Undangan. Depok: Kementerian Hukum dan Hak Asasi Manusia, 2018.

- Proses Penyusunan Peraturan Daerah. Depok: Kementerian Hukum dan Hak Asasi Manusia, 2018. http://bpsdm.kemenkumham.go.id/index.php/course/modul-bestpractice-kumham.

Effendi, Lutfi. Pokok-Pokok Hukum Administrasi. 1st ed. Malang: Bayu Media, 2003.

Ganjong. Pemerintahan Daerah Kajian Politik Hukum. 1st ed. Bogor: Ghalia Indonesia, 2007.

Hadjon, Philipus M. Pengantar Hukum Administrasi Indonesia. Yogyakarta: Universitas Gadjah Mada, 1997.

Kelsen, Hans. General Theory of Law and State. 1st ed. New York: Routledge, 2005.

Kementerian Hukum dan HAM, and Japan International Cooperation Agency. Buku Tanya Jawab Seputar Pembentukan Peraturan Perundang-Undangan Di Tingkat Pusat. Jakarta: Kementerian Hukum dan Hak Asasi Manusia, 2019.

Soekanto, Soerjono, and Sri Mamudji. Penelitian Hukum Normatif: Suatu Tinjauan Singkat. 17th ed. Jakarta: Rajawali Press, 2015.

Soeprapto, Maria Farida Indrati. Ilmu Perundang-Undangan: (Jenis, Fungsi, Dan Materi Muatan). Jakarta: Kanisius, 2007.

\section{Regulations}

Constitutional Court Decision No 137-PUU-XII_2015.

Constitutional Court Decision No. 56/PUU-XIV/2016.

\section{Others}

Bawono, Adi Condro. "Perbedaan Keputusan Dengan Peraturan." Hukum Online, 2012. https://www.hukumonline.com/klinik/detail/ulasan/lt4f0281130c750/perbedaankeputusan-dengan-peraturan/.

Boemiya, Helmy. "Teori Kewenangan Dan Sumber-Sumber Kewenangan (Atribusi, Delegasi, Dan Mandat)." wordpress, 2014. https://boeyberusahasabar.wordpress.com/2013/12/10/sumber-kewenangan-atribusidelegasi-dan-mandat/.

KBBI. “Arti Konsiderans.” In Kbbi. KBBI, 2021. https://kbbi.web.id/konsiderans.

Suantra, I Nengah. "Naskah Tutorial Teori Legislasi Dalam Pembentukan Peraturan Daerah." Denpasar,

https://simdos.unud.ac.id/uploads/file_pendidikan_1_dir/82772d18fda11e83fed7290646 195f01.pdf. 